\title{
The Main Dramatic Features of Melodrama: A Dramatic Study of Maria Martin and Sweeney Todd And Their Traces In Modern Soap Operas
}

\author{
Lutfi Hamadi, (PhD) \\ Lebanese University, Lebanon
}

doi: 10.19044/esj.2017.v13n26p122 URL:http://dx.doi.org/10.19044/esj.2017.v13n26p122

\begin{abstract}
This paper attempts an exploration of the prosperity of melodrama in the nineteenth century with its literary shortcomings in comparison with more serious and deeper plays before and after that era. Shedding light on the political, social, and economic changes that took place in Europe in general and in England in particular, this study tries to show how melodrama reflected these changes and represented the new rising middle class with all their values, beliefs, and interests. In addition, the paper shows similarities between melodrama and modern soap operas and movies, with their artificially fabricated plots and endings, unconvincing characters, and irrational incidents and coincidences. For this purpose, the study will trace the main dramatic features of melodrama and mark them out in two of the most notable melodramas of that period, namely Maria Martin and Sweeney Todd, which were adapted and produced cinematically. The paper will conclude how changes in different aspects of society are definitely reflected on the literary works during a certain period of time. The methodology will include an historical overview, shedding light on the changes that took place in England in the $19^{\text {th }}$ century, comparing and contrasting melodramas and other more important literary forms, together with the two plays to be studied as examples. To achieve credibility, the paper will refer to works by remarkable thinkers and critics in the field, illustrate by using quotes from both plays, and interpret and analyze their function and importance.
\end{abstract}

Keywords: $19^{\text {th }}$ century melodrama shortcomings, social changes, new values, soap operas

\section{Introduction}

This paper attempts an exploration of the dramatic features of melodrama, a genre that permeated the British theatres in the $19^{\text {th }}$ century, and an analysis of these features in two well-known melodramas of that era, 
Maria Martin Or The Murder in the Red Barn (1840) by an anonymous writer and The String of Pearls or Sweeney Todd (1847) by George Dibdin Pitt. The purpose of this study is to shed light on the literary shortcomings of melodrama in an attempt to trace the origin of today's TV melodrama and its prosperity mainly in TV soap operas and other types of series nowadays be it Mexican, Turkish or Indian among many others, in addition to countless movies of the same type. Such works have a lot in common with the $19^{\text {th }}$ century British melodrama, which is negatively influenced by and in turn influences the public taste because of its striking superficiality and excessive use of illogical coincidences and exaggerations. Using dubbing instead of subtitles nowadays seems to have the intention of even sparing the viewers the effort of reading subtitles. The paper focuses on Maria Martin and Sweeney Todd because they not only served as important material in the $19^{\text {th }}$ century but are also considered as prototypes of English Melodrama, in addition to having been both produced cinematically. To achieve its purpose, the paper will include a variety of methods. Comparison and contrast will be used to show the shortages of this genre in comparison with other remarkable literary forms, and will also compare and contrast the two melodramas mentioned above. Besides, an historical background will be used to spot light on the social, economic, and political factors that had led to the emergence of this theatrical type, reflecting the level of education and interests of a new rising class. Analysis, interpretation, and exemplification will be also employed, referring to remarkable critics and writers and using quotes from the two plays.

\section{I.}

The term melodrama has come from Greek "Melos", meaning "song", and originally meant a spoken text with musical plays including opera. This genre evolved in the eighteenth century, where in Germany, the term "melodrama" was used to describe a text in opera, spoken accompanied by orchestra. In France, however, it "was applied to the device, invented some years earlier by Jean-Jacques Rousseau in his monologue 'Pygmalion', whereby music expressed a character's emotion when he was silent" (Oxford, 525). In Italy, it was applied to "a play with music, each being given equal importance" (528)

Nowadays, when melodrama is mentioned in literary cycles, it is usually said with some contempt referring to a literary dramatic genre "solely concerned with action and a direct appeal to the heart"(Kilgariff, 1974, 14), and characterized by falsity, bombast and cheapness. Some scholars even go further and simply say that there was no drama in England between Richard Brinsley Sheridan, whose last play, Pizarro, was in 1799 and Bernard Shaw, whose first play, Widower's Houses was in 1892. This definitely confirms 
the fact that for about a century the English theater suffered from dire poorness to the extent that not a single up-to-the-level play appeared.

In England, melodrama emerged and flourished in the $19^{\text {th }}$ century, which, according to critics, saw the steady decline of the British drama as a serious art form. Regardless of the various factors that led to this decline, it gave way to other much less important types of plays besides melodramas: farces, spectacles, and extravaganzas, of which melodramas and farces were the only recognized genres, referred to as "legitimate" and monopolized by "Drury Lane" and "Covent Garden" theatres. The latter performed the first melodrama in England, A Tale of Mystery, which Thomas Holcroft adapted from the French René-Charles Guilbert de Pixérécourt's Coelina; ou, L'Enfant $d u$ Mystere without taking the effort to even include any acknowledgment.

As a matter of fact, melodrama witnessed its golden age throughout the $19^{\text {th }}$ century depending mainly on poor translations from French. In fact, it was not until the last quarter of the century that the genre started to take a British touch, and the typical melodrama began to decline with the advent of Henry Arthur Jones, Sir Arthur Wing Pinero, and Oscar Wilde. Those authors' plays tended to deal more deeply with life, paving the way to a more serious and more literary accepted drama.

It is worth mentioning that while flourishing, melodrama took a variety of types, reflecting the changing values and interests of the British society. With the beginning of the decline of the aristocracy and the rise of a new middle class, significant changes started to take place in different aspects of life where some values and mores started to disappear, leaving room to new ones more appropriate to the mentality and lifestyle of the rising class of merchants and business people. Unlike the nobility, the members of this class were not highly educated and had a different taste, expecting to go to the theater to relax and have fun rather than think deep about sophisticated literary plays. According to Juliet John (2009), Pixérécourt, one of the most important $19^{\text {th }}$-century French writers of melodrama, declared openly that he was "'writing for those who cannot read'. In consequence, he developed 'a melodramatic artistry aimed entirely at an unlettered populace"" (2). Thus one could see among the most popular types of melodrama: the Gothic or Romantic, the Nautical, the Social, and the Domestic melodrama. Despite this diversity, still these different types have specific common features as for themes, characterization, plots, language, and scenic effects.

In an attempt to reflect the strict moral code of the period, the central theme of melodrama was that of morality facing villainy, so melodramas revolved around the basic conflict between virtue and vice. Commenting on the change of themes in correspondence with the changing values of each age, Disher (1954) writes, “Shakespeare's audiences liked blood, Restoration 
wits preferred sex, eighteenth-century exquisites favored sentiment and Victorians demanded morals." (xiii).

Unlike modern drama, where dramatists go deeper in man's inner self with the line between good and evil not that clear, and the individual's personality is too complicated to be simply judged that way, characters of melodrama simply represent absolute good or absolute evil. With no exception, the good is rewarded and the evil is punished; just like the early American movies, where the good hero always defeats the bad guys. Those melodramas dealt with a variety of themes: oppression, rebellion, seduction, slavery, unsuccessful love relationships, among several others; yet, according to Allardyce Nicoll (1966), who wrote several remarkable works on drama, including melodrama, "excitement, exaltation of virtue and poetic justice appear in all... spiced with a little pathetic humanitarianism and a dash of ghostliness" (History, 105).

As clear as it is, all the melodramas end with contentment and relief, if not with happiness, as "heroes prosper while villains die miserably" (Disher, xiv), and, surprisingly enough, many were the melodramas that connected innocence with poverty and vice with wealth, an implicit indication to the immoral acts thought to be committed by the previous powerful aristocrats against housemaids and peasants, a theme tackled by many European novelists in that period such as Thomas Hardy's Tess of the d'Urbervilles.

Another distinctive feature of melodrama is its prototypes, simplistic, one-dimensional characters, which were composed in terms of romanticized sentimentalism. Marcia Landy (1991) summarizes some of these characters as

The fallen woman, the prostitute, the helpless woman beleaguered in her chastity, the brutal, alcoholic, and philandering husband and father, and the cruelly abandoned child all inhabit the landscape of the nineteenth-century and early twentieth-century domestic melodramas from the theater to the cinema (286).

Heroes and heroines are usually good, kind-hearted, and loyal. They are ready to sacrifice heroically for the sake of love and to save the typical innocent helpless heroine. However, the villain, in turn, is the central figure, without whom the play wouldn't exist. His mere appearance on the stage would stir the new semi-educated $19^{\text {th }}$-century audience, who would hiss him and applaud the hero. This villain would take different roles: a ruthless offender, a senseless murderer, a "formentor of conspiracies, deviser of snares, abductor of maidness, and persecutor of innocence" (Rahill, 1967, 12). This same villain's social status would change with the change of the 
type of the melodrama, so he could be an avaricious employer, a lecherous landlord, or a wicked squire. Characterization in melodrama went even further where the external features of the character reflected the internal, thus the good ones certainly looked so good and the bad ones looked ugly. Consequently, you could see those playing bad roles dyed in black or distorted in one way or another.

It is worth mentioning too that despite the gloomy, full-of-blood, and Gothic atmosphere of melodrama, rarely does one of them lack scenes of humour, cheap humour to be accurate. According to Michael Booth (1973), "Oddly coexisting with intensely melodramatic elements were equally strong components of low comedy and eccentric characterization that provided most of its humour" (4). Thus the $19^{\text {th }}$-century melodrama audience did not only expect but also looked forward to and laughed hard at despicable scenes of humour taking place by unreal characters and mostly had nothing to do with the plot of the play.

The sensational serious plots spiced with superficial scenes and artificial ends are another feature of melodrama. It highly depended on poorly-structured dramatic situations, typically providing a fabricated problem that usually ended with comfort and satisfaction. Not unlike many contemporary TV soap operas nowadays, almost impossible coincidences and illogical incidents decide a character's destiny: a vicious housemaid, for example, is engaged in a conspiracy against the innocent protagonist and is certainly able to know every single detail about his/her life; all of a sudden, to cite another example, a strong love relationship or a prepared marriage is blown up when out of nowhere somebody appears to declare that this affair is impossible because the lovers are in fact a brother and sister. In this respect, Martha Vicinus (1981) describes the $19^{\text {th }}$-century melodrama as an excess of emotion, disproportionate to the object, excessively simplified characters who appeal to each other and the audience by means of exaggerated expressions of right or wrong, and many remarkable and improbable coincidences, spectacular effects, and plot complications. As the taste for these extremes has declined, melodrama has fallen into disrepute, despite its continued lively existence in soap operas, movies, and best-selling novels. (127)

Sarcastically enough, not only the characters but also the audience get emotionally involved and hysterical crying and never-ending screams would pervade the scene.

In addition, melodramatic plots with heightened emotionalism and sentimentality were carried out by the excessive use of various effects. In an attempt to capture the audience's senses, to explain the rising action, disclose 
plans, and create thrilling situations, playwrights resorted to mimetic action, songs, asides, and scenic visual effects - all accompanied by incidental music. Involving the audiences to some degree in the dramatic world of the play was a successfully common technique, where audiences felt emotionally involved and participated actively with their spontaneous responses. Such audience would altogether shout to discourage Maria Martin from going to the red barn, or to warn Mark not to sit in Sweeney Todd's chair. This is not that weird for a $19^{\text {th }}$-century audience when compared to some viewers nowadays going far by internalizing with and addressing TV characters in a similar way. In many cultures, these viewers insist on calling the actors by their names in certain movies or series, not their real names. Commenting on how melodrama used to get the audience involved, Nicoll, in his British Drama (1962), explains that "plots were explained to the spectators partly by the use of mime, partly by the introduction of a few songs, and partly by the display of title boards" (201-202). In English Drama (1973), Nicoll clarifies that "asides are plentiful in the dialogue, and emphatic melodramatic capitals are freely used to give force to the scenes" (187). Asides were directly addressed to the audience mainly to help develop the rising action and partly to lure and excite the audience. Nicoll considers that the excessive use of asides in melodrama is a weakness because it was easier for playwrights to give stage directions than to write dialogues (History, 102). It can also be noted that for the sake of more sensational thrills, all kinds of gorgeous effects were employed such as "explosions, noises off, coloured fire, 'engines', trap doors..." (Kilgariff 20). Another important feature in many melodramas and plays a role in intensifying the dramatic situations or fabricating an end to the story is reference to dreams and ghosts - a technique mainly used in gothic melodramas at a time people strongly believed in that.

This paper will trace all these features in two important $19^{\text {th }}$-century melodramas, namely Maria Martin and Sweeney Todd, which can be considered perfectly typical samples as they include most, if not all, of the features mentioned above.

Although based on a real incident which took place on May 18, 1827, or perhaps because of that, Maria Martin or The Murder in the Red Barn is almost a perfect model of the melodrama of that era, concerning the theme, since it clearly portrays the conflict between good and evil, between absolute morality and absolute wickedness. As in a typical melodrama, virtue is embodied in Maria and her poor family of farmers, while vice is represented by William Corder, the son of the local squire. Corder, the typical villain, convinces helpless Maria and her simple-minded parents that he is going to marry her secretly after she has given birth to his illegitimate child. Maria, being truly in love with Corder, soon agrees, and upon his request, she goes 
disguised to meet him in the red barn where, as discovered later, she is killed and buried.

The play begins with Maria alone in her parents' cottage worried about Corder's being late. Since the very beginning, the audience comes to know how innocent and loyal Maria is and sympathizes with her as she, ironically enough, tells her brother, George, "William is dear to my happiness. My every hope of life, of future joys, is centered in him" (215). It doesn't take us long, however to discover Corder's ill intentions as in his first appearance, he speaks his mind addressing the audience, "The deed were bloody, sure; but I will do it, and rid me of this hated plague" (216). Although George tells her he has seen Corder kissing the milkmaid, Maria and her mother show that they have full confidence in him, which raises more emotionalism and sentimentality, showing Maria a perfect melodramatic victim, trustful and naïve as she is. While Corder is working on his devilish plot, he tells Maria and her mother that he is waiting for the magistrates to legalize his marriage and his child. To heighten the dramatic situation and for melodramatic necessities, Maria tells her mother that she knows "his nature - open as his heart - will never rest till he secures that peace he has destroyed." Her mother is by no means less naïve, thus answering, "Poor fellow! Pray heaven his success may equal his exertions, and all may yet go well"(217). Nonetheless, it is not a melodrama where action happens all at once. It is essential for the audience to be emotionally stirred to the maximum, to the very extremes, extreme uprightness and extreme immorality. Thus, we see Corder kind of hesitant about carrying out his plan:

Am I turned coward, or what is it makes me tremble thus? Have I not heart sufficient for the deed? Or do I falter with remorse of conscience? No, by heaven and hell 'tis false! (219).

As if this is not enough to show how vicious Corder is, he simply declares he will strangle Mr. Martin to death if he knows that he has heard him talking about his plan in an aside. Absolutely nothing is going to deter him from getting rid of Maria after having already killed the baby.

On the other hand, the play digresses on how honesty, kindness and love lie at the core of the Martins' relationships. The father, though at a moment does not feel positive about Corder's feelings towards his daughter and wonders what she finds in him, it does not take him long to change his mind, considering what Corder is doing "a generous, noble act" which "Heaven will reward him for it" (220); consequently, he grants him his blessings.

The play goes on this way emphasizing the heroine's gullibility and innocence in contrast with the rogue's evil and black-heartedness. Just before 
he commits his murder, Corder reaffirms his fiendish plan saying in an artificially sophisticated language, "The storm that lust began must end in blood" (32). The scene of the murder is typically melodramatic. Guileless Maria still clings to Corder's promise to marry her, to which he responds:

Marry thee! You cannot think me so lost. "Tis time the mask should fall, [...] I brought you here not to marry you ... swear to keep the murder of our child a secret, and renounce all pretensions of becoming my wife, or, by Heaven, you never quit this spot alive (225).

Needless to say, honest Maria stubbornly refuses this and in spite of all her implores, Corder, the perfect melodramatic scoundrel kills her and buries her in the already prepared grave.

It is worth mentioning that albeit falling in adultery and having an out-of-wedlock child, Maria is not only understood but also unequivocally forgiven and sympathized with by her parents and the $19^{\text {th }}$-century audience as well. The best description of Maria as a melodramatic heroine is perhaps what M. Wilson Disher calls a "Magdalen", the woman in Luke's Gospel who wept for her sins. In dozens of melodramas there was the popular protagonist who was "chaste in soul though guilty in deed" (Disher 1). However, the Victorian audience, despite all the strict moral codes of the era, was ready to overlook this sin and see in her the poor victim seduced by a devilish aristocrat, who exploits her poverty and misery. It might appear that the play ends with the death of Maria. However, it is not a melodrama that ends this way. The catharsis is still to come and the divine justice has to prevail, so the audience would leave the theater at least content, if not happy. This echoes traditional Arabian nights when the audience would get angry and beg the story-teller not to stop with the protagonist in jail or facing any other critical situation.

Unsurprisingly, the disclosure of the murder comes under the persistence of Maria's mother, who sees in her dream for three consecutive nights that her daughter is buried in the red barn! So the father and the enthusiastic neighbors search the barn and discover the corpse. It is not unusual in a melodrama that dreams play such a role. Corder himself has a dream in which he sees Maria dressed in white wandering in the fields and pausing twice to look at the red barn. In no time and before finishing his soliloquy, an officer arrives to arrest him. Soon after, Corder is convicted and condemned to death. Only then could the curtain fall and would the melodrama audience let out steam and feel comfort and satisfaction.

Though Maria Martin is supposedly a play of blood and murder, as a typical melodrama, it should include some humor. To solicit laughter, four of the eleven scenes the play is composed of are dedicated for comic purposes, namely scenes two and four in Act I and scenes two and five in Act II, where 
clown-like characters, namely Timothy and Johnny have nothing to do with the plot and are seen on the stage for no purpose except to amuse the audience. Even in the last minute before Corder's execution, these characters get involved in a silly artificially fabricated fight, ending Johnny's repeated phrase, "I want my ma" (234), which would every time arouse laughter among the $19^{\text {th }}$-century audience.

Furthermore, as in most melodramas, the characters in Maria Martin excessively address the audience and use asides to create artificial pathos and thrilling situations. To mention a few examples out of many, as the curtain rises at the beginning of the play, Maria is alone speaking to the audience, expressing her anxiety that Corder is late. Similarly, in his first appearance, Corder uses an aside to uncover his real fiendish personality and plans (216). In the same scene, he uses another aside to comment ironically on Mrs. Martin's relying on him to protect Maria and her unshakable belief that he knows "the proper steps to take"; thus saying, "Ay that I do" (217). Again and again, asides are used several times not only by Corder but also by other characters as well. For example, they are used three times by Maria in scene two and once by Mr. Martin in scene three. Though relatively very short and no more secret plans are to be divulged, Act II includes two asides. The first is said by Corder, who is supposed to be horrified that his murder is discovered, what he unexpectedly thinks of is showing surprise at the idea that Maria's corpse was discovered in the morning of his dream, while the second aside is used by Johnny for the sake of soliciting laughter.

As for music and scenic effects, they are used, but perhaps not excessively in comparison with supernatural and nautical melodramas. Still music is used almost at the end of each scene and in all serious critical situations. Chord is used after soliloquies, and music, of no specified kind, goes on continuously while Corder is carrying out his murder. Chords are played twice by the end of scene 4, Act II, while music of different kinds (slow, Ghost, bell tolls) is prominent in the last scene in addition to blue fire and the appearance of Maria's spirit rising at the back of the stage. All this seems necessary for a melodramatic atmosphere, an atmosphere of excitement, sentimentality, and Gothicism.

Like almost all melodramas, dreams play a crucial role in Maria Martin. Without her mother's recurrent dream, Maria's corpse would have never been found. Similarly, to raise emotion and create a melodramatic atmosphere, artificially poetic and bombastic language is heavily used in the play. The language used by Mrs Martin in the wake of her dream is a good example. Describing the predicament of old age and feeling of imminent death, Mrs Martin tells her husband, "Yes, Thomas, we are fast declining in the vale of life and soon must be overtaken by death, who hovers o'er our heads ever ready to place his icy fingers on our hearts" (227). Likewise, the 
scene of murdering Maria is only lengthened to arouse pathos and suspense, which necessitates the use of pompous language. Thus while reminding Maria of threatening him to disclose the act of murdering their child, Corder says, "Would it had never been spoken, for it hath roused a scorpion here, that doth gnaw and lash me on to vengeance" (224)! Similarly, Maria resorts to such an artificially wrought language to beseech Corder to spare her life. She implores:

Oh, William, thy fame is dear to me as my blood. What have I not sacrificed for thy love? Am I not a creature lost in shame, for men to point at and women to mock? Am I not a poor, forlorn, frail thing, whose heart is bruised and bleeding with excess of agony - whose form is bowed with suffering miseries (225).

The String of Pearls or Sweeney Todd is perhaps one of the most thrilling and macabre melodramas ever written to the extent that it is still adapted by Hollywood. The latest Sweeney Todd: The Demon Barber of Fleet Street was produced in 2007 with Johnny Depp as Sweeney.

In fact, modern adaptations of both plays have undergone a lot of changes from the original ones. Though keeping the melodrama atmosphere, more characters and incidents are introduced in an attempt to make the plays less illogical and more enjoyable. In the new version of Sweeney Todd, for example, Sweeney is given an excuse for his crimes and he is there to revenge the raping and killing of his wife. Anyway, back to the original one, although Sweeney Todd tells a totally different story from that of Maria Martin, the theme and characterization are not of a different nature. Nor is much dissimilar the use of music, scenic effects, mimetic action, asides and appalling humor.

Like Maria Martin, Sweeney Todd clearly glorifies traditional values and melodramatically attempts to arouse artificial pathos by idolizing virtue and reproving greed and wickedness. The villain this time, Sweeney Todd, is an avaricious barber, who senselessly slaughters his innocent customers and, using his movable chair, sends them down to his accomplice, Mrs. Lovett, to use their flesh for her 'delicious' pies. The play starts with Sweeney humiliating his poor apprentice, Tobias, when a sea captain, Mark, arrives for a shave he badly needs to meet his beloved, whom he has not seen for years. After he sees the valuable string of pearls with the captain, Sweeney sends Tobias out and sends Mark down to his fate in the oven of Mrs. Lovett's bakery.

When his neighbor Jean Parmine, who is by no means less greedy than Sweeney, fails to buy the string at a meager price, he threatens to take him to the magistrate. Needless to say, after a short fight Sweeney sends him down too. In the horrible dark cellar, Jean meets Mrs. Lovett's new worker 
Jarvis Williams, and they both take a new lease of life when they manage to run away after watching Sweeney murdering Mrs. Lovett, who wanted her share of the "profits". Having doubts that Tobias might know something about his "business", Sweeney tries to keep him silent by threatening to report his poor mother, who once had to steal a candle-stick from her coldhearted, severe employer to pay the rent. Again, using one of the mostly clichéd melodramatic devices - a direct contrast - to show the huge difference between a light offense committed by the needy and underprivileged and a series of horrible, premeditated murders by the powerful, Sweeney Todd, not unlike Maria Martin, definitely sympathizes with the miserable, wretched poor. Eventually Sweeney pays Jonas, a madhouse manager, to lock Tobias up there, so he would die just like Sweeney's previous apprentice. When Jonas tells Tobias that he will die "with no power can aid you," Tobias, a symbol of the impoverished and illfated, and in a clear attempt to arouse the emotions of the audience, answers, "Yes, there is one! Heaven - which fails not to succour the helpless and persecuted" (258). Yet, fortunately and in a typically melodramatic scene, Tobias is saved by Jarvis after a heroic fight with a large number of the madhouse keepers. In the same respect at another point of the play, Jarvis, who is in rags and desperately needs a job, reacts to Mrs. Lovett's contemptuous treatment, saying "Ay, that is the way of the world. There is always sufficient argument by the rich against the poor and destitute to keep 'em so; but argifying don't mend the matter" (252).

Parallel to this absolute evil embodied by the devilish Sweeney is the absolute purity and innocence symbolized by Mark's fiancée, Johanna. Like Maria, Johanna is the forlorn heroine who is the target of scoundrels the like of Dr. Lupin, who just wants to "extinguish the flame by the moisture of those ruby lips" (251). Yet, Johanna is as pure as snow and so loyal and faithful to Mark, who had to travel and earn enough so that they could get married. Even Colonel Jeffery, who is investigating Mark's disappearance, falls in love with her. Johanna appears here in an extremely emotional scene, and when she is told the bad news, she responds that "a sick bed may be my resting-place till I exchange it for a coffin" (250). Similar to Maria, she also appears as a melodrama prototype heroine: pretty, innocent, and distressed. In addition, it is not uncommon in a melodrama that Colonel Jeffery turns out to be as simple minded as Johanna, so he is easily tricked by Sweeney's devilish scheme and he is arrested with the string of pearls in his hand.

However, the seemingly more complicated plot of Sweeney Todd cannot but have the same irrational happy ending. During the trial, and while Sweeney is giving his testimony, Mark's ghost appears to him; so, typically melodramatic, the tough murderer breaks down and confesses his murder. This obviously reflects the failure to create a deliberate, logical ending, thus 
the writer's resort to such a fast, unreasonable solution. This is not unlike a lot of TV series nowadays, where all of the complications and problems that could take hundreds of episodes come to be solved all of a sudden in the very last episode. Worse, to create more than contentment, it miraculously appears that Mark is still alive. Again virtue gloriously triumphs, while evil is totally defeated.

Other than those mentioned above, many are other irrational events and coincidences that overflow from Sweeney Todd. To cite a few examples, none of the characters that succeed to escape death like Jarvis and Jean, strangely goes to the police. Sweeney, illogically and for no clear reason, chooses Colonel Jeffery, who also happened to be on the boat with Mark on the way back home, to make him responsible for the murder, and not less strangely, the latter is easily tricked. Finally, Tobias does not see dead Pirelli's hand dangling out of the chest he sits on. In addition, as Maria's spirit rises at the back of the stage in the last scene, the appearance of Mark's ghost plays a crucial role in bringing the play to its happy ending.

Different from Maria Martin, Sweeney Todd doesn't employ full scenes for humor; however, the play is not without some kind of low comedy. Sweeney's distinctive exaggerated laugh is itself a source of laughter; besides, the play excessively uses pun to arouse laughter. In scene one, Act I, Sweeney repeats the phrase "to polish a customer off" several times; in scene four, the same Act, Jarvis talks about " the delicious odour of the pies", which are made of human flesh and full of hair, bones, and buttons, while Sweeney tells Mrs. Lovett in the same scene that he will "balance accounts" with her. Similarly, instead of saying he needs a shave, Jean tells Sweeney, "I would have you shave me" (248). Another example of using pun for the sake of laughter is Mrs. Lovett's response to Jarvis's question about her previous worker. In an implication that he was killed, and in a threatening tone, she tells Jarvis, "He has gone to some of his oldest friends, who will be glad to see him. ... Everybody who relinquishes this situation goes to his old friends, friends that he has not seen for many years" (252-253)! Furthermore, like Timothy and Johnny in Maria Martin, the main reason for Dr Lupin's presence is to arouse laughter. While drunk, Dr. Lupin flirts Johnna, and calling himself 'pious', he offers her his bottle to give her "spiritual consolation" (251). The scene ends with Lupin's calling for help after being hit hard by Colonel Jeffery, thus "The household run in armed with brooms and mops" (251). All the scene is nothing but ghastly humour .

Not unlike Maria Martin, Sweeney Todd is full of asides where characters address the audience to explain thoughts and plans. For example, in the first scene of Act I, Sweeney uses asides three times, in two of which he tells the audience that he has to get rid of someone, while in the third, he counts his savings out of what he takes from his victims, and soon he will 
have a hundred thousand pounds (248). In turn, Jeffery, Jarvis, Mrs. Lovett, and Johanna use asides at different points of the play mainly to unfold their feelings, worries, and expectations.

As a typical melodrama, Sweeney Todd utilizes the service of music and different types of scenic effects for the mere purpose of creating more thrills, suspense and spectacle, though not as much as Maria Martin does. From scene four Act I on, music and effects are used incessantly. Lights are used to show the furnace door with "a fierce glare lights the stage" (254). Stage directions for a "picture" are used at the very end of scene one Act II and at the end of scene two Act II, while the play ends with a "Tableau."

Finally, pompous language is abundantly used in Sweeney Todd to raise corniness. Like Maria's words while talking about love and emotions, almost all of what Johanna and Lupin say is merely bombastic to express their different types of passion. In Act I, scene two, Johanna says:

I suppose it is too much for human nature to expect two blessings at once. I had the fond warmed heart that loved me, without the fortune that would have enabled us to live in comfort, and now, when that is, perchance, within my grasp, the heart which was by far the most costly possession, lies buried in a grave - its bright influences, its glorious aspirations quenched forever (250).

One more example is when Jarvis surprisingly quotes Shakespeare, an attempt by the writer as it seems to add some flavor of knowledge and education. Expressing his reluctance to work with Mrs. Lovett, he tells her, "As Shakespeare says, "My poverty, and not my will consents"” (252).

\section{Conclusion}

To summarize, both plays, more or less, show the distinctive features of $19^{\text {th }}$-century melodrama, which reflected the dominant mood and values of the Victorian Age, showing in turn how political, social, and economic changes undoubtedly leave their impact on the literary production . Most important of these are: the continuous theme of goodness and virtue defeating evil and wickedness; the unconvincing characters that represent absolute good and innocence or absolute viciousness and malice; the exaggerated, poorly-constructed plots that end artificially with the dominance of justice; the merging of the comic with the serious and pathetic; and finally, the excessive use of asides, music, scenic effects, and bombastic language which are utilized for more thrills and more emotionalism. Anyway, no matter how many the literary shortcomings of melodrama are, a genre that pervaded the theatres in England for a whole century is still worth studying. However, one cannot but wonder, if such a genre could be 
understood to attract an illiterate or a semi-literate audience in the $19^{\text {th }}$ century England, how are melodramatic TV series thriving and enthusiastically watched by the supposedly educated audience in the $21^{\text {st }}$ century?

\section{References:}

1. Anonymous. (1840). Maria Martin (the Murder in the Red Barn.) In Kilgarrif, (Ed.) The Golden Age of Melodrama (pp 213-235).

2. Booth, M. R. ed. (1973). English Plays of the Nineteenth Century. Vol III. Oxford: Clarendon Press.

3. The Concise Oxford Companion to the Theatre. (1996). $2^{\text {nd }}$ ed. Oxford University Press.

4. Dibdin, G. (1847). The String of Pearls (Sweeney Todd). In Kilgarrif, (Ed.), The Golden Age of Melodrama (pp 237-262).

5. Disher, M. W. (1954). Melodrama: Plots that Thrilled. London: Rockliff.

6. John, J. (2009) "Melodrama and its Criticism: An Essay in Memory of Sally Ledger." In Interdisciplinary Studies in the Long Nineteenth Century.(8).

$10.16995 / \mathrm{ntn} .496 /$ galley/356

7. Kilgariff, M. ed. (1974). The Golden Age of Melodrama: Twelve $19^{\text {th }}$ Century Melodrama. London: Wolfe.

8. Landy, M. (1991). British Genres: Cinema and Society, 1930-1960. Princeton University Press. Retrieved from: //www.jstor.org/stable/j.ctt7zvvm6.13.

9. Nicoll, A. (1966). A History of English Drama 1660-1900. Vol IV. Cambridge University Press.

10. Nicoll, A. (1962). British Drama. London: Harrap.

11. Nicoll, A. (1973) English Drama 1900-1930: The Beginnings of the Modern Period. Cambridge University Press.

12. Rahill, F. (1967). The World of Melodrama. Pennsylvania: State University Press.

13. Vicinus, M. (1981). "Helpless and Unfriende: Nineteenth-Century Domestic Melodrama." New Literary History. Vol 13, No. 1. The Johns Hopkins University Press. Retrieved from http://www.jstor.org/stable/468646

14. Wheeler, H. Sweeney Todd, the Demon Barber of Fleet Street. Retrieved from http://gl1t6h.tripod.com/Sweeney_Todd_Libretto.pdf 